\title{
Protective effect of in-feed specific IgM towards Yersinia ruckeri in rainbow trout
}

Chettri, Jiwan Kumar; Al-Jubury, Azmi; Hansen, Marie B.; Lihme, Allan; Dalsgaard, Inger; Buchmann, Kurt; Heegaard, Peter M. H.

\section{Published in:}

Fish and Shellfish Immunology

Link to article, DOI:

10.1016/j.fsi.2019.08.024

Publication date:

2019

Document Version

Peer reviewed version

Link back to DTU Orbit

Citation (APA):

Chettri, J. K., Al-Jubury, A., Hansen, M. B., Lihme, A., Dalsgaard, I., Buchmann, K., \& Heegaard, P. M. H. (2019). Protective effect of in-feed specific IgM towards Yersinia ruckeri in rainbow trout. Fish and Shellfish Immunology, 93, 934-939. https://doi.org/10.1016/j.fsi.2019.08.024

\section{General rights}

Copyright and moral rights for the publications made accessible in the public portal are retained by the authors and/or other copyright owners and it is a condition of accessing publications that users recognise and abide by the legal requirements associated with these rights.

- Users may download and print one copy of any publication from the public portal for the purpose of private study or research.

- You may not further distribute the material or use it for any profit-making activity or commercial gain

- You may freely distribute the URL identifying the publication in the public portal 


\section{Journal Pre-proof}

Protective effect of in-feed specific IgM towards Yersinia ruckeri in rainbow trout

Jiwan K. Chettri, Azmi Al-Jubury, Marie B. Hansen, Allan Lihme, Inger Dalsgaard, Kurt Buchmann, Peter M.H. Heegaard

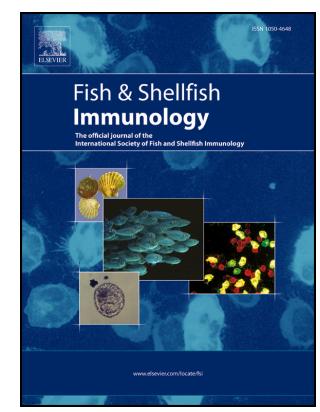

PII: S1050-4648(19)30824-1

DOI: $\quad$ https://doi.org/10.1016/j.fsi.2019.08.024

Reference: $\quad$ YFSIM 6366

To appear in: Fish and Shellfish Immunology

Received Date: 22 February 2019

Revised Date: 8 August 2019

Accepted Date: 9 August 2019

Please cite this article as: Chettri JK, Al-Jubury A, Hansen MB, Lihme A, Dalsgaard I, Buchmann K, Heegaard PMH, Protective effect of in-feed specific IgM towards Yersinia ruckeri in rainbow trout, Fish and Shellfish Immunology (2019), doi: https://doi.org/10.1016/j.fsi.2019.08.024.

This is a PDF file of an article that has undergone enhancements after acceptance, such as the addition of a cover page and metadata, and formatting for readability, but it is not yet the definitive version of record. This version will undergo additional copyediting, typesetting and review before it is published in its final form, but we are providing this version to give early visibility of the article. Please note that, during the production process, errors may be discovered which could affect the content, and all legal disclaimers that apply to the journal pertain.

() 2019 Published by Elsevier Ltd. 
${ }^{a}$ National Veterinary Institute, Technical University of Denmark, Frederiksberg C, Denmark

\begin{abstract}
Tightened regulations and an environmentally friendly approaches in fish production have greatly reduced the use of antibiotics but green solutions are continuously being explored. The use of functional feed may have a potential in the aquaculture sector in securing biomass and minimizing the loss from disease. In the present study, we tested the concept that blood from the fish slaughterhouse can be used for mass purification of specific antibodies which subsequently can be used for feeding fish and thereby confer protection against diseases. IgM was purified from serum from Yersinia ruckeri vaccinated rainbow trout and an IgM sandwich ELISA was developed for quantification of rainbow trout IgM. The purified IgM was encapsulated in alginate microparticles and top-coated in fish feed. IgM re-extracted from the alginate microparticles was shown to retain high reactivity towards $Y$. ruckeri antigens indicating that its bioactivity remained intact after encapsulation. IgM release from the alginate microparticles was only observed at high $\mathrm{pH}(\mathrm{pH}$ 8.2) and minimal at low $\mathrm{pH}$, indicating protection of $\operatorname{IgM}$ at low $\mathrm{pH}$ in the fish stomach during passage. In a feeding challenge experiment (feeding 1 week before Y. ruckeri challenge and for two weeks following challenge), a statistically non-significant $10 \%$ lower mortality was observed in the high dose (400 $\mu \mathrm{g}$ IgM/fish/day fed over 3 weeks) group.
\end{abstract}

\title{
Introduction
}

The annual growth of the aquaculture sector has exceeded $7.8 \%$ in the $1990-2010$ period [1] making it the fastest growing food producing sector globally. Intensive fish farming systems face a number 
of challenges, including increased risk of disease outbreaks with associated environmental and animal welfare issues, but immunoprophylactic control measures may reduce disease problems. Vaccination is generally applied when fish are immune-competent and have well-developed immune organs but vaccine-induced protection may not always be achievable when considering young and not fully immune-competent stages. Alternative methods of protection, such as passive immunization using specific antibodies, may confer protection to young and vulnerable fish. A series of studies have documented that vaccine-induced protection is in many cases directly related to production of specific antibodies [2-4] which in rainbow trout comprise $\operatorname{IgM}, \operatorname{IgT}$ and $\operatorname{IgD}$ where $\operatorname{IgM}$ represents the systemic immunoglobulin, whereas $\operatorname{IgT}$ and $\operatorname{IgD}$ contribute to protection of mucosal surfaces [5-7]. Passive immunization of fish against bacterial pathogens, such as Vibrio anguillarum, V. vulnificus and Streptococcus sp., has been demonstrated to confer protection in larger fish [8-10]. Oral administration of specific antibodies may be a solution for small fish however the conditions (low $\mathrm{pH}$, proteolytic activity) in the stomach represent a problem. Digestive degradation of antigens by low $\mathrm{pH}$ and proteolytic conditions and antigens or proteins should be protected in such an environment. The use of a low cost biodegradable polymer, such as alginate, may offer resistance to proteolysis without being immunogenic and toxic. Alginate is one of the most used polymers for microencapsulation [11] and the alginate from brown algae has been successfully used for oral vaccination of Atlantic salmon, Salmon salar against Y. ruckeri [12]. Recently, it was shown that the feeding of weaning piglets with $\operatorname{IgG}$ purified from pig slaughterhouse blood significantly reduced disease and shedding of pathogenic bacteria, and at the same time maintained ileal microbial diversity, suggesting its applicability in controlling postweaning diarrhea in piglets [13]. The present study was conducted to test a parallel concept in fish for controlling early stage diseases by making use of fish slaughterhouse blood containing specific immunoglobulins against different pathogens obtained through active vaccination or through 
environmental exposure during the grow-out phase. To test this concept, IgM with high activity against $Y$. ruckeri was purified from fish vaccinated with $Y$. ruckeri and encapsulated in alginate microparticles. The IgM containing alginate microparticles were then top-coated in fish feed and fed to rainbow trout fry to evaluate the protective effect of orally administered immunoglobulin against subsequent $Y$. ruckeri challenge by immersion exposure.

\section{Materials and Methods}

\subsection{Vaccination}

Rainbow trout $(\mathrm{N}=35$, total body weight $0.5-0.6 \mathrm{~kg})$ were vaccinated with an experimental vaccine containing formalin-killed whole cell Y. ruckeri bacterin (biotype 1 and 2) [14] in combination with Freund's incomplete adjuvant (FIA) (vaccine:adjuvant, (vol:vol), 1:1; water-in-oil emulsion). The final adjuvanted vaccine contained $3 \times 10^{10} \mathrm{CFU} / \mathrm{ml}$ and was administered by intraperitoneal injection (IP: $0.1 \mathrm{ml}$ ). Booster vaccination (IP) was applied three weeks (315 degree days) post primary vaccination and blood samples were taken 7 weeks (735 degree days) post primary vaccination. Fish were kept at $15^{\circ} \mathrm{C}$ and daily fed with pelleted feed (2\% of biomass). Blood samples from unvaccinated fish $(\mathrm{N}=50 ; 1.5-2.5 \mathrm{~kg})$ were used as a control.

\subsection{Blood sampling}

Fish were euthanized by MS222 (ethyl 3-aminobenzoate methanesulfonate; Sigma-Aldrich A5040) immersion (concentration $100 \mathrm{mg} / \mathrm{l}$ ) and blood samples from 35 immunized and 10 non-immunized fish by caudal vein puncture (BD Vacutainer®). Serum was recovered by centrifugation (3000 x $g$ ) for 10 min at $4{ }^{\circ} \mathrm{C}$ and kept at $-80^{\circ} \mathrm{C}$ for later analysis.

\subsection{ELISA}

\section{Specific ELISA to measure antibody titer}

Serum samples were analysed for $Y$. ruckeri specific antibody titers using ELISA $[2,15]$. In brief: microtiter plates (flat-bottom 96-well plates, MaxiSorp ${ }^{\mathrm{TM}}$, Nunc) were coated with sonicated 
bacterial lysate at $5 \mu \mathrm{g} / \mathrm{ml}$ protein concentration (Y. ruckeri $\mathrm{O} 1$ biotype 2$)$ in bicarbonate coating buffer (Sigma-Aldrich Cat. No. C3041, Denmark) and incubated overnight in a refrigerator. Nonspecific binding sites were hereafter blocked with $2 \%$ bovine serum albumin (BSA, Sigma-Aldrich, A4503) in PBS with $0.1 \%$ Tween 20 for $1 \mathrm{~h}$ at room temperature followed by four times washing in PBS-T (PBS with 0.1\% Tween 20) and plates were stored at $-20^{\circ} \mathrm{C}$ until further use. Serum samples in duplicate were incubated overnight at $4^{\circ} \mathrm{C}$ in antigen coated plates, followed by washing and incubation with mouse anti-salmonid Ig (AbD Serotec, Dusseldorf, Germany) (dilution:1:500) and HRP (horseradish peroxidase) conjugated rabbit anti-mouse IgG (AbD Serotec Dusseldorf, Germany) (dilution1:500) for $1 \mathrm{~h}$ at room temperature. After every step, plates were washed 4 times in PBS-T. To optimize a working dilution, two representative samples from each group were run in 10 fold dilution series (1/50 to 1/500 000) and two serum dilutions (where the non-specific binding was minimal) were chosen for the final analysis. As a final step plates were incubated with substrate TMB (tetramethylbenzidine) PLUS (AbD Serotec, Dusseldorf, Germany) for 5-10 min and the reaction was stopped by adding $1 \mathrm{~N} \mathrm{HCL}$ whereafter optical density (OD) was measured at $450 \mathrm{~nm}$ using an Epoch Spectrophotometer (BioTek Instruments, Inc., Winooski, USA).

\subsection{Preparation of IgM loaded alginate particles}

Alginate encapsulation of IgM molecules was performed by a previously described method [16]. Briefly, purified concentrated IgM $(91.8 \mathrm{mg} / \mathrm{ml})$ was combined with $630 \mathrm{mg}$ medium viscosity alginate from brown algae (Sigma-Aldrich, A2033) dissolved in $20 \mathrm{ml}$ distilled water and mixed in a magnetic stirrer for $20 \mathrm{~min}$ at room temperature. The aqueous phase (alginate containing IgM) was then added slowly to an oil phase containing $37 \mathrm{ml}$ octane and $3 \mathrm{ml}$ of Span-80 (continuous stirring with a handheld pitched-blade homogenizer at $300 \mathrm{rpm}$ ). Then, $3 \mathrm{ml}$ of Tween-80 was added and the emulsification procedure was continued for $1 \mathrm{~h}$ at room temperature at $500 \mathrm{rpm}$ 
whereafter $7.7 \mathrm{ml}$ of $8 \%$ aqueous solution of calcium chloride was added dropwise to facilitate gelation of microparticles through ionic crosslinking by calcium cations. The mixture was stirred for $1 \mathrm{~h}$ at room temperature at $200 \mathrm{rpm}$. In order to harden the microparticles , $10 \mathrm{~mL}$ isopropyl alcohol was added and allowed to stir at room temperature for 30 mins. The microparticles were collected by centrifuging at $250 \mathrm{~g}$ for 10 mins and collected microparticles were washed twice with isopropyl alcohol. The final product was washed in distilled water $(2 \mathrm{x})$, lyophilized overnight and stored at $4{ }^{\circ} \mathrm{C}$ until use. Using this procedure, four types of IgM-loaded alginate microparticles was prepared: (i) IgM from Y. ruckeri vaccinated fish $(50 \mathrm{mg}, 250 \mathrm{mg}$ and $500 \mathrm{mg}$ ); (ii) IgM from unvaccinated fish (250 mg) and (iii) only plain alginate microparticles (no IgM encapsulation).

\subsection{Evaluation of stability of alginate encapsulated IgM at different $\mathrm{pH}$ and determination of} bioactivity

The release of IgM from alginate encapsulation was tested by incubating $20 \mathrm{mg}$ of encapsulated microparticles in $1 \mathrm{ml}$ solution at different $\mathrm{pH}(\mathrm{pH}=2.7,5,7,7.7,8.2$ and 10, respectively (glycine, sodium acetate, PBS, milliq water, EDTA, sodium bicarbonate and sodim phosphate) for 4 days at room temperature or at $4^{\circ} \mathrm{C}$. Hereafter, $100 \mu \mathrm{l}$ of the incubated solution was used for running the $Y$. ruckeri specific ELISA to analyse for release of bio-active IgM. A total of $32.5 \mu 1$ of the incubated solution was used for running SDS- PAGE and Western blot to check if the IgM had been degraded during the process.

\subsection{Coating of fish feed with IgM-loaded alginate microparticles}

Fish feed (commercial $2 \mathrm{~mm}$ pellets, Aller Aqua A/S) was top-coated with alginate microparticles and sealed with vegetable oil. The encapsulated microparticles containing different amounts of $\operatorname{IgM}$ (50 mg, $250 \mathrm{mg}$ and $500 \mathrm{mg}$ ) was added to $50 \mathrm{~g}$ of feed and mixed by gentle stirring while continuously being sprayed with an fine oil spray. In a similar way, $250 \mathrm{mg}$ of anti-Yersinia $\operatorname{IgM}$ as 
well as oxolinic acid (1.25 g/kg feed; Sigma-Aldrich O0240000) was directly top-coated with vegetable oil. All coated feed were stored at $4{ }^{\circ} \mathrm{C}$.

\subsection{Feeding and challenge experiment}

Rainbow trout (Oncorhynchus mykiss) fry produced in a re-circulated pathogen-free facility (Salmon hatchery Bornholm, Nexø, Denmark) were transported to our experimental facility at the University of Copenhagen, Denmark. Fish were acclimatized in our facility for 1 week at $15^{\circ} \mathrm{C}$ and distributed in the experimental tanks. A total of eight groups in duplicate (average body weight $2 \mathrm{~g}$; 25 fish/tank; 16 tanks with 20 L volume) were included in the experiment. Three control groups in duplicate were included: One group fed with ordinary feed coated with plain alginate (this group was not given infection and served as uninfected control; group 1). A second group fed the same way but exposed to $Y$. ruckeri infection (infected control; group 2). The third control group was given alginate encapsulated IgM supplemented feed purified from the unvaccinated fish (250 mg IgM per $50 \mathrm{~g}$ feed or $200 \mu \mathrm{g} \mathrm{IgM/fish/day)} \mathrm{and} \mathrm{exposed} \mathrm{to} \mathrm{infection} \mathrm{(group} \mathrm{3).} \mathrm{The} \mathrm{three} \mathrm{treatment}$ groups were fed different levels of anti-Yersinia ruckeri encapsulated immunoglobulin: 50, 250 and $500 \mathrm{mg}$ IgM per $50 \mathrm{~g}$ feed (corresponding to $40 \mu \mathrm{g}$ IgM/fish/day, $200 \mu \mathrm{g}$ IgM/fish/day and $400 \mu \mathrm{g}$ $\operatorname{IgM/fish/day;~group~4,~group~} 5$ and group 6, respectively). The seventh group (group 7) of fish was fed with anti-Yersinia ruckeri immunoglobulin directly oil coated on feed $(250 \mathrm{mg}$ IgM per $50 \mathrm{~g}$ feed corresponding to $200 \mu \mathrm{g}$ IgM/fish/day). Finally, group 8 was fed with antibiotic (oxolinic acid: $1.25 \mathrm{~g} / \mathrm{kg}$ feed; Sigma-Aldrich O0240000) coated feed (positive control). The experimental groups are detailed in Table 1.

Fish was fed $2 \%$ of body weight (40 mg feed/fish/day) with different codes of feed comprising 40 $\mu \mathrm{g}$ IgM/fish/day, $200 \mu \mathrm{g} \mathrm{IgM/fish/day} \mathrm{and} 400 \mu \mathrm{g} \mathrm{IgM/fish/day.} \mathrm{Fish} \mathrm{were} \mathrm{fed} \mathrm{once} \mathrm{in} \mathrm{the} \mathrm{morning}$ by slowly adding feed to individual tanks ensuring total consumption of the added feed. After 1 week of feeding with experimental feed, fish were exposed to experimental infection: Water from 
each tank was lowered to $5 \mathrm{~L}$ and fish were exposed (duration $4 \mathrm{~h}$ ) to a $48 \mathrm{~h}$ culture of $Y$. ruckeri (100415-1/4) with a final bacterial concentration of $1.2 \times 10^{8} \mathrm{CFU} / \mathrm{ml}$ by adding $50 \mathrm{ml}$ of culture broth. Hereafter clean water was added to the tank reaching a water volume $20 \mathrm{~L}$. On the following day, water was exchanged with fresh tap water to remove bacteria from the tank. In the uninfected group control (Group 1, Table 1), sterile LB medium was added (sham infection) and treated otherwise as infected groups. The fish were continuosly fed with experimental feed for 2 weeks after exposure whereafter the experiment was terminated. Fish were closely observed following the infection, any fish swimming abruptly, swimming at the surface with asphyxia and showing severe sign of disease were euthanized in a high dose of MS222 (ethyl 3-aminobenzoate methanesulfonate; Sigma-Aldrich A5040) and recorded as mortality. Bacteria from freshly euthanized fish (samples from head kidney, spleen and brain) were re-isolated on blood agar plates for confirmation of specific cause of death.

\section{Statistical analysis}

Mortality data were analyzed by Kaplan-Meier survival analysis and are presented as cumulative mortality (\%). Two-tailed unpaired t-test with Welch's correction was applied for testing ELISA data. For determining the concentration of $\operatorname{IgM}$, a standard curve was plotted and analyzed with non-linear regression (curve fit) with Sigmoidal four points logistic (4PL) and the concentration of unknown samples was interpolated based on the standard curve (appendix II). The data were considered significant when $\mathrm{P} \leq 0.05$.

\section{Results}

\subsection{ELISA}

Fish vaccinated with $Y$. ruckeri antigens showed a significantly higher pathogen-specific antibody level (although with a considerable variation) than the unvaccinated control group (Fig. 1).

\subsection{IgM loaded alginate microparticles}


Alginate microparticles loaded with anti-Yersinia antibody were exposed to various $\mathrm{pH}$ conditions and IgM release measured using a sandwich ELISA designed to quantify IgM concentration (Appendix I \& II). The highest IgM release at alkaline pH 8.2 (sodium bicarbonate), a lower release at $\mathrm{pH} 10$ (sodium phosphate $0.1 \mathrm{M}$ ) but no or minimal release of $\operatorname{IgM}$ at low or neutral $\mathrm{pH}$. The recovered IgM from alginate beads showed a high bioactivity (binding to $Y$. ruckeri) antigens and no loss of bioactivity due to the gelation process was detected (Fig. 3). This was further confirmed by SDS-PAGE (Fig. 4-left) and Western blot (Fig. 4-right) showing that the IgM remained intact after the gelation process.

\subsection{Feeding and challenge experiment}

Fish were fed $2 \%$ of body weight per day corresponding to specific IgM feeding levels of $40 \mu \mathrm{g}$ IgM/fish/day (50 mg), $200 \mu \mathrm{g} \mathrm{IgM/fish/day} \mathrm{(250} \mathrm{mg)} \mathrm{and} 400 \mu \mathrm{g} \mathrm{IgM/fish/day} \mathrm{(500} \mathrm{mg).} \mathrm{Fish} \mathrm{were}$ fed IgM encapsulated feed for 1 week before challenge with Y. ruckeri and during the course of infection. The control IgM (from un-vaccinated fish) were offered to fish as $200 \mu \mathrm{g} \operatorname{IgM} /$ fish/day (250 mg). No protective effect of feeding with specific IgM on the survival from lethal challenge with Y. ruckeri was observed (Fig. 5). The challenge bacterium was re-isolated from all the euthanized fish and was confirmed by MALDI-TOF MS (matrix-assisted laser desorption ionization-time of flight mass spectrometry). Only the group fed with oxolinic acid (antibiotic) showed a significantly lower mortality. Rainbow trout offered feed with the highest anti-Yersinia IgM concentration showed a $10 \%$ lower mortality $(\mathrm{p}>0.05)$ than the infected control group and delay in onset of mortality was observed in this group. Fish fed un-specific IgM also showed a trend for a lower mortality. An enhancing effect of alginate encapsulation was noted when comparing mortality patterns between the $\operatorname{IgM}$ (only top-coated with oil) and $\operatorname{IgM}$ encapsulated in alginate microparticles (250 mg IgM) (Fig. 5).

\section{Discussion}


193 Fish possess an adaptive immune system with an ability to mount a specific antibody response against pathogens. However, early life stages (fish larvae and fry), have not yet developed a fully functional immune response and rely to a wide extent on innate immune molecules and maternal transfer of vital immune factors (complement factors, SAA, serine proteases, and immunoglobulin) for survival and well-being of young fish $[17,18]$. Transfer of immunoglobulin from mother to offspring occurs in fish [19-22] and this vertical transmission confers protection [23] which frames the importance of securing immunized brood fish for generation of healthy offspring [24]. Passive immunization (transfer of immune serum to naive fish by injection) has shown to enhance protection for more than 2 months post administration against vibriosis caused by Vibrio anguillarum [20]. Passive immunization by use of oral administration of fish serum containing specific immunoglobulin from immunized fish would be a less laborious and less costly method. However, preliminary trials could not document enhanced survival in rainbow trout fingerlings following challenge with Vibrio anguillarum but the lack of protection could be due to proteolysis of antibodies in the gastro-intestinal tract of salmon [25]. We evaluated the effect of alginateencapsulation to overcome the degradation in the gut as intact antibodies, protected against proteolysis, could confer short-term immunity until the young fish is fully immune-competent and able to respond to vaccination. This approach would be equally beneficial in protecting larger fish or high-value fish which are close to harvesting but are at high risk to disease outbreak and for which active vaccination is not an option. In the present study, blood harvested from vaccinated fish with high antibody titers against $Y$. ruckeri was used for the production of alginate encapsulated IgM microparticles which subsequently were applied for the feeding of rainbow trout fry. In order to optimize precision in the study we further developed and validated a sandwich ELISA for quantification of IgM from rainbow trout using a mouse monoclonal anti-salmon antibody [26, 27] as both catching and detection antibody (supplementary material II). Oral active immunization 
applying alginate encapsulated bacterial cells was previously demonstrated to be effective in boosting immune response and increasing protection of salmon $[12,28]$ which suggests that alginate encapsulation is a useful technology for delivery of cells, proteins and low molecular weight drugs [29]. In the present study alginate from brown algae was used for encapsulation of purified IgM from vaccinated or un-vaccinated fish. The in vitro incubation experiment suggests that $\operatorname{IgM}$ is protected from degradation at acidic conditions as there was no release of $\operatorname{IgM}$ at $\mathrm{pH} 2$ and merely partial discharge of IgM occurred at higher $\mathrm{pH}$ (maximum at $\mathrm{pH} 8.2$ and minor release at $\mathrm{pH}$ 10). Analysis of gut samples would have shed more light on the quantity of specific IgM delivered into the gut and its intestinal release, but was not performed in the present study. However, previous studies suggest that alginate microcapsules are retained in the gut lumen or found in the intestinal epithelium within $1.5 \mathrm{~h}$ and in the lamina propia $6 \mathrm{~h}$ after oral administration [16]. We showed that the bio-activity of $\operatorname{IgM}$ remained intact as re-harvested $\operatorname{IgM}$ from alginate microparticles showed a strong binding towards $Y$. ruckeri antigen as tested by pathogen-specific ELISA. This indicates that there is no deleterious effect of the emulsification and gelation process on the activity of anti-Yersinia IgM which supports previous studies showing that the immunogenicity of antigen or protein are not affected by the process $[12,16]$.

Our in vivo studies (feeding a diet containing anti-Yersinia ruckeri $\operatorname{IgM}$ ) did not show a significantly enhanced survival of fish challenged with $Y$. ruckeri but a tendency towards protection (10\%) was observed for the fish group fed the highest IgM dose (400 $\mu \mathrm{g} / \mathrm{fish} / \mathrm{day})$. The bacterial dose used for challenge may have been too high compared to the administered amount of IgM and a lower challenge dose may allow a better segregation between differently IgM-dosed groups. Future studies should therefore elucidate if increased IgM levels in feed and/or a lowered infection pressure result in elevated protection. It may be speculated that $\operatorname{IgM}$ reaching the gut in feed may bind to and inactivate a pathogen in the lumen or within the intestinal wall and/or that 
elevated IgM levels at bacterial entry portals (anal opening, intestine, stomach, gills, lateral line, epidermis, dorsal fins and olfactory bulb [30,31] may delay or prevent invasion. As IgM is a high molecular weight protein its uptake from the gut to the circulation is unlikely unless M-cells assist the process but such a scenario should be further investigated.

\section{Acknowledgments}

Authors would like to thank fish keepers at the Bornholm Salmon Hatchery and at the fish keeping facility at the Technical University of Denmark. The technical assistance of Henriette Vorsholt, Kári Karbech Mouritsen and productive discussions with Lone Madsen, Chris Juul Hedegaard and Prof. Niels Lorenzen are highly appreciated. The project was funded of the Green Development and Demonstration Programme (GUDP) under "IMMFEED: Immunoglobulin for Fish Productioncombating infections without antibiotics" project no. 34009-14-0795.

\section{References}

[1] M. Troell, R.L. Naylor, M. Metian, M. Beveridge, P.H. Tyedmers, C. Folke, K.J. Arrow, S. Barrett, A.S. Crepin, P.R. Ehrlich, A. Gren, N. Kautsky, S.A. Levin, K. Nyborg, H. Osterblom, S. Polasky, M. Scheffer, B.H. Walker, T. Xepapadeas, A. de Zeeuw, Does aquaculture add resilience to the global food system?, Proc Natl Acad Sci U S A 111(37) (2014) 13257-63.

[2] J.K. Chettri, S. Deshmukh, L. Holten-Andersen, R.M. Jafaar, I. Dalsgaard, K. Buchmann, Comparative evaluation of administration methods for a vaccine protecting rainbow trout against Yersinia ruckeri $\mathrm{O} 1$ biotype 2 infections, Vet Immunol Immunopathol 154(1-2) (2013) 42-7.

[3] S. Deshmukh, P.W. Kania, J.K. Chettri, J. Skov, A.M. Bojesen, I. Dalsgaard, K. Buchmann, Insight from Molecular, Pathological, and Immunohistochemical Studies on Cellular and Humoral Mechanisms Responsible for Vaccine-Induced Protection of Rainbow Trout against Yersinia ruckeri, Clinical and vaccine immunology : CVI 20(10) (2013) 1623-41.

[4] K. Rømer Villumsen, I. Dalsgaard, L. Holten-Andersen, M.K. Raida, Potential Role of Specific Antibodies as Important Vaccine Induced Protective Mechanism against Aeromonas salmonicida in Rainbow Trout, PLOS ONE 7(10) (2012) e46733.

[5] I. Hordvik, Immunoglobulin isotypes in Atlantic salmon, Salmo salar, Biomolecules 5(1) (2015) 166-77.

[6] Y.-A. Zhang, I. Salinas, J. Li, D. Parra, S. Bjork, Z. Xu, S.E. LaPatra, J. Bartholomew, J.O. Sunyer, IgT, a primitive immunoglobulin class specialized in mucosal immunity, Nature Immunology 11(9) (2010) 827-835. [7] J. Skov, J.K. Chettri, R.M. Jaafar, P.W. Kania, I. Dalsgaard, K. Buchmann, Effects of soluble immunostimulants on mucosal immune responses in rainbow trout immersion-vaccinated against Yersinia ruckeri, Aquaculture 492 (2018) 237-246.

[8] M. Akhlaghi, Passive immunisation of fish against vibriosis, comparison of intraperitoneal, oral and immersion routes, Aquaculture 180(3-4) (1999) 191-205. 
[9] M. Akhlaghi, B.L. Munday, R.J. Whittington, Comparison of passive and active immunization of fish against streptococcosis (enterococcosis), Journal of Fish Diseases 19(3) (1996) 251-258.

[10] B.R. LaFrentz, C.A. Shoemaker, Passive transfer of serum from tilapia vaccinated with a Vibrio vulnificus vaccine provides protection from specific pathogen challenge, Aquaculture 442 (2015) 16-20.

[11] L. Chan, H. Lee, P. Heng, Production of alginate microspheres by internal gelation using an emulsification method, International journal of pharmaceutics 242(1-2) (2002) 259-62.

[12] B. Ghosh, T.D. Nguyen, P.B.B. Crosbie, B.F. Nowak, A.R. Bridle, Oral vaccination of first-feeding Atlantic salmon, Salmo salar L., confers greater protection against yersiniosis than immersion vaccination, Vaccine 34(5) (2016) 599-608.

[13] C.J. Hedegaard, M.L. Strube, M.B. Hansen, B.K. Lindved, A. Lihme, M. Boye, P.M.H. Heegaard, Natural Pig Plasma Immunoglobulins Have Anti-Bacterial Effects: Potential for Use as Feed Supplement for Treatment of Intestinal Infections in Pigs, PLOS ONE 11(1) (2016) e0147373.

[14] R.M. Jaafar, J.K. Chettri, I. Dalsgaard, A. Al-Jubury, P.W. Kania, J. Skov, K. Buchmann, Effects of adjuvant Montanide $^{\mathrm{TM}}$ ISA 763 A VG in rainbow trout injection vaccinated against Yersinia ruckeri, Fish \& Shellfish Immunology 47(2) (2015) 797-806.

[15] J.K. Chettri, J. Skov, R.M. Jaafar, B. Krossøy, P.W. Kania, I. Dalsgaard, K. Buchmann, Comparative evaluation of infection methods and environmental factors on challenge success: Aeromonas salmonicida infection in vaccinated rainbow trout, Fish \& Shellfish Immunology 44(2) (2015) 485-495.

[16] B. Ghosh, B.F. Nowak, A.R. Bridle, Alginate Microencapsulation for Oral Immunisation of Finfish: Release Characteristics, Ex Vivo Intestinal Uptake and In Vivo Administration in Atlantic Salmon, Salmo salar L, Marine biotechnology (New York, N.Y.) 17(6) (2015) 841-53.

[17] M. Lovoll, T. Kilvik, H. Boshra, J. Bogwald, J.O. Sunyer, R.A. Dalmo, Maternal transfer of complement components C3-1, C3-3, C3-4, C4, C5, C7, Bf, and Df to offspring in rainbow trout (Oncorhynchus mykiss), Immunogenetics 58(2-3) (2006) 168-79.

[18] P. Swain, S.K. Nayak, Role of maternally derived immunity in fish, Fish \& Shellfish Immunology 27(2) (2009) 89-99.

[19] A. Hanif, V. Bakopoulos, G.J. Dimitriadis, Maternal transfer of humoral specific and non-specific immune parameters to sea bream (Sparus aurata) larvae, Fish \& Shellfish Immunology 17(5) (2004) 411435.

[20] L.W. Harrell, H.M. Etlinger, H.O. Hodgins, Humoral factors important in resistance of salmonid fish to bacterial disease. I. Serum antibody protection of rainbow trout (Salmo gairdneri) against vibriosis, Aquaculture 6(3) (1975) 211-219.

[21] A. Mor, R.R. Avtalion, Transfer of antibody activity from immunized mother to embryo in tilapias, Journal of Fish Biology 37(2) (1990) 249-255.

[22] Y.M. Sin, K.H. Ling, T.J. Lam, Passive transfer of protective immunity against ichthyophthiriasis from vaccinated mother to fry in tilapias, Oreochromis aureus, Aquaculture 120(3) (1994) 229-237.

[23] P. Swain, S. Dash, J. Bal, P. Routray, P.K. Sahoo, S.K. Sahoo, S. Saurabh, S.D. Gupta, P.K. Meher, Passive transfer of maternal antibodies and their existence in eggs, larvae and fry of Indian major carp, Labeo rohita (Ham.), Fish \& Shellfish Immunology 20(4) (2006) 519-527.

[24] S. Oshima, J. Hata, C. Segawa, S. Yamashita, Mother to fry, successful transfer of immunity against infectious haematopoietic necrosis virus infection in rainbow trout, The Journal of general virology 77 ( $\mathrm{Pt}$ 10) (1996) 2441-5.

[25] M.E. Nielsen, K. Buchmann, Effects of Oral Administration of Specific Antibodies to Rainbow Trout Oncorhynchus mykiss, Journal of the World Aquaculture Society 34(1) (2003) 11-17.

[26] J.K. Chettri, M.K. Raida, P.W. Kania, K. Buchmann, Differential immune response of rainbow trout (Oncorhynchus mykiss) at early developmental stages (larvae and fry) against the bacterial pathogen Yersinia ruckeri, Developmental \& Comparative Immunology 36(2) (2012) 463-474.

[27] M.M. Olsen, P.W. Kania, R.D. Heinecke, K. Skjoedt, K.J. Rasmussen, K. Buchmann, Cellular and humoral factors involved in the response of rainbow trout gills to Ichthyophthirius multifiliis infections: Molecular and immunohistochemical studies, Fish \& Shellfish Immunology 30(3) (2011) 859-869. 
[28] J.L. Romalde, A. Luzardo-Alvárez, C. Ravelo, A.E. Toranzo, J. Blanco-Méndez, Oral immunization using alginate microparticles as a useful strategy for booster vaccination against fish lactoccocosis, Aquaculture 327 236(1-4) (2004) 119-129.

[29] K.Y. Lee, D.J. Mooney, Alginate: Properties and biomedical applications, Progress in Polymer Science 329 37(1) (2012) 106-126.

330 [30] U. Khimmakthong, S. Deshmukh, J.K. Chettri, A.M. Bojesen, P.W. Kania, I. Dalsgaard, K. Buchmann, 331 Tissue specific uptake of inactivated and live Yersinia ruckeri in rainbow trout (Oncorhynchus mykiss): 332 visualization by immunohistochemistry and in situ hybridization, Microbial pathogenesis 59-60 (2013) 3333341.

334 [31] M. Ohtani, K.R. Villumsen, E.O. Koppang, M.K. Raida, Global 3D Imaging of Yersinia ruckeri Bacterin Uptake in Rainbow Trout Fry, PLOS ONE 10(2) (2015) e0117263. 
Table 1. The experimental set-up used for testing the protective effect of feeding Yersinia ruckeri specific IgM encapsulated in alginate microparticles. Each group consisted of 50 fish divided into duplicate ( 25 fish/tank) and fish were fed with medicated feed for 1 week before challenge infection and 2 weeks during the infection period. The water level was lowered to $5 \mathrm{~L}$ during the challenge infection and fish was exposed to $1.2 \times 10^{8} \mathrm{CFU} / \mathrm{ml}$ concentration of bacteria soup for $4 \mathrm{~h}$. The experiment was conducted at $15^{\circ} \mathrm{C}$ for 3 weeks and moribund fish were euthanized using a high dose of MS222.

\begin{tabular}{|c|c|c|c|c|c|}
\hline $\begin{array}{l}\text { Group } \\
\text { no. }\end{array}$ & Groups & Feed coated with: & $\begin{array}{c}\text { IgM } \\
\text { concentration }\end{array}$ & No. of fish/group & $\begin{array}{l}\text { Challenge infection } \\
\text { Bath exposure for } 4 \mathrm{~h}\end{array}$ \\
\hline 1 & Uninfected control & Plain alginate microparticles & 0 & 50 & No \\
\hline 2 & Infected control & Plain alginate microparticles & 0 & 50 & $1.2 \times 10^{8} \mathrm{CFU} / \mathrm{ml}$ \\
\hline 3 & Un-specific IgM & Alginate microparticles with un-specific IgM & $200 \mu \mathrm{g} /$ fish/day & 50 & $1.2 \times 10^{8} \mathrm{CFU} / \mathrm{ml}$ \\
\hline 4 & Anti-Yersinia IgM & Alginate microparticles with anti-Yersinia IgM & $40 \mu \mathrm{g} /$ fish/day & 50 & $1.2 \times 10^{8} \mathrm{CFU} / \mathrm{ml}$ \\
\hline 5 & Anti-Yersinia IgM & Alginate microparticles with anti-Yersinia $\operatorname{IgM}$ & $200 \mu \mathrm{g} /$ fish/day & 50 & $1.2 \times 10^{8} \mathrm{CFU} / \mathrm{ml}$ \\
\hline 6 & Anti-Yersinia IgM & Alginate microparticles with anti-Yersinia $\operatorname{IgM}$ & $400 \mu \mathrm{g} /$ fish/day & 50 & $1.2 \times 10^{8} \mathrm{CFU} / \mathrm{ml}$ \\
\hline 7 & Anti-Yersinia IgM & Feed oil coated with anti-Yersinia IgM & $200 \mu \mathrm{g} /$ fish/day & 50 & $1.2 \times 10^{8} \mathrm{CFU} / \mathrm{ml}$ \\
\hline 8 & Oxolinic acid & Feed oil coated with Oxolinic acid $(1.25 \mathrm{~g} / \mathrm{kg})$ & 0 & 50 & $1.2 \times 10^{8} \mathrm{CFU} / \mathrm{ml}$ \\
\hline
\end{tabular}




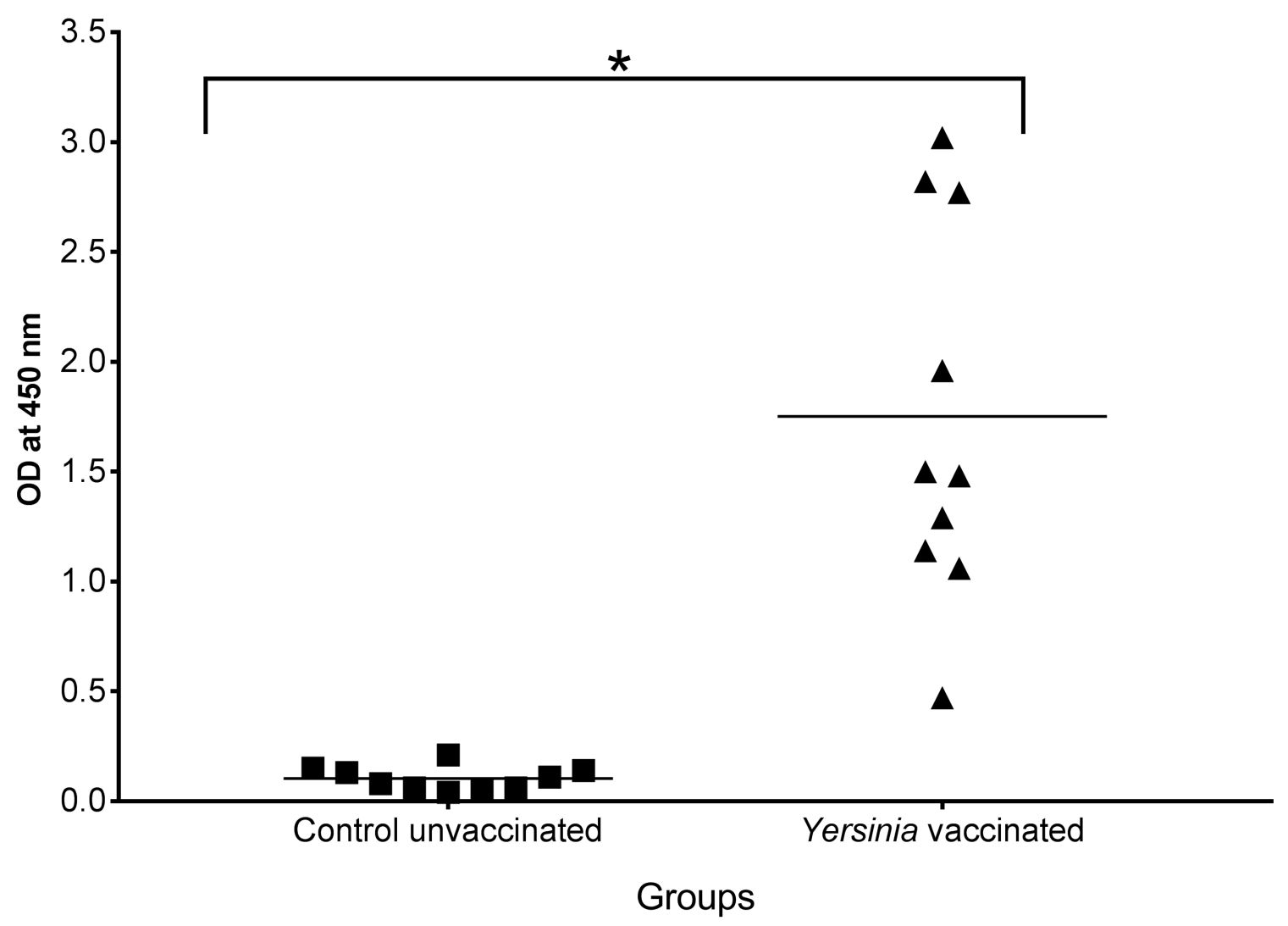




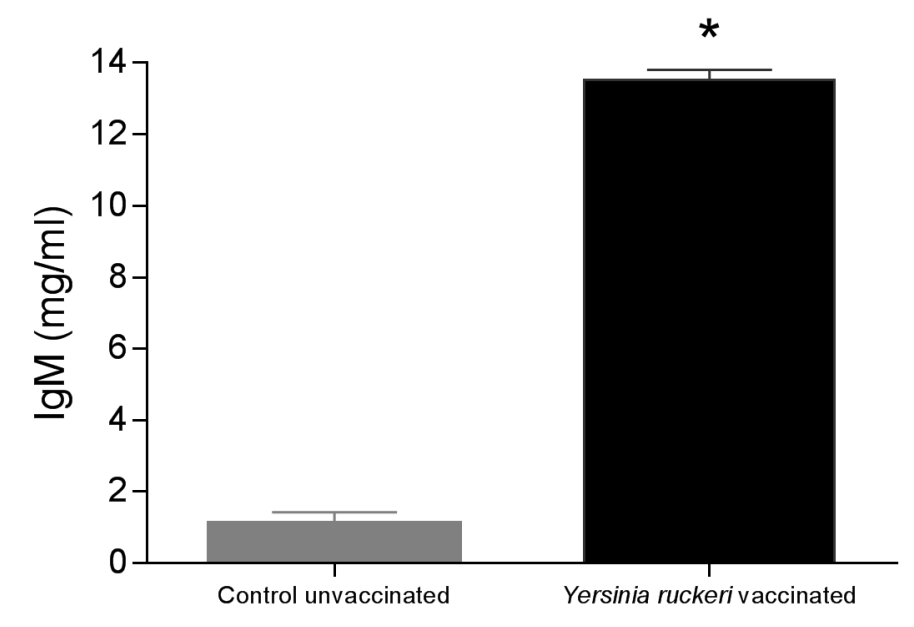




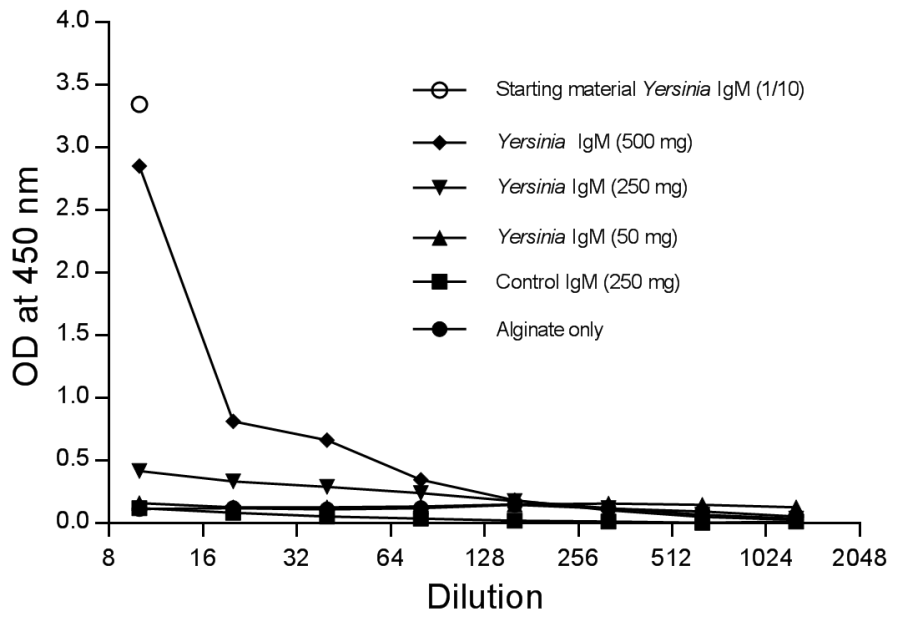




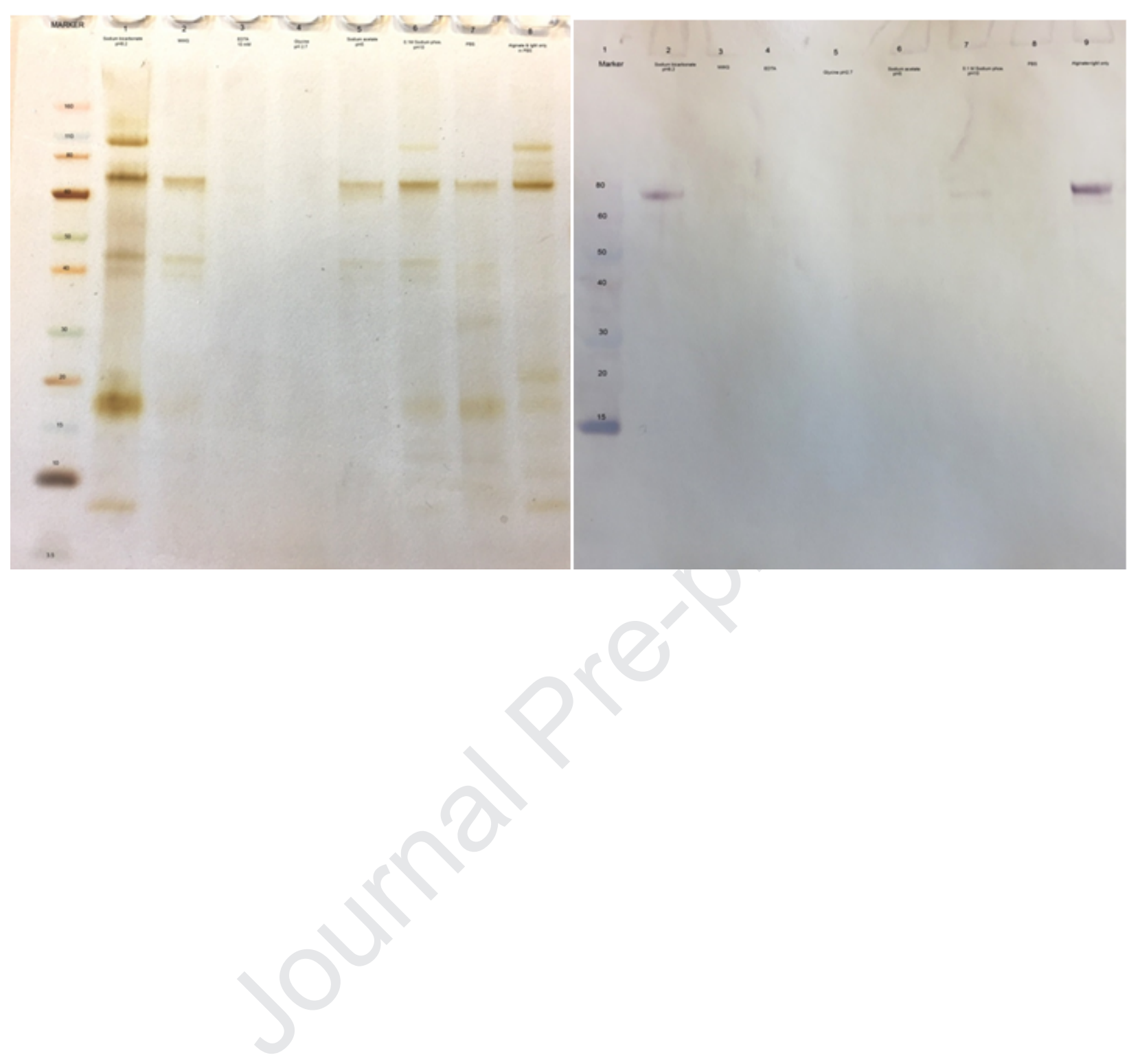




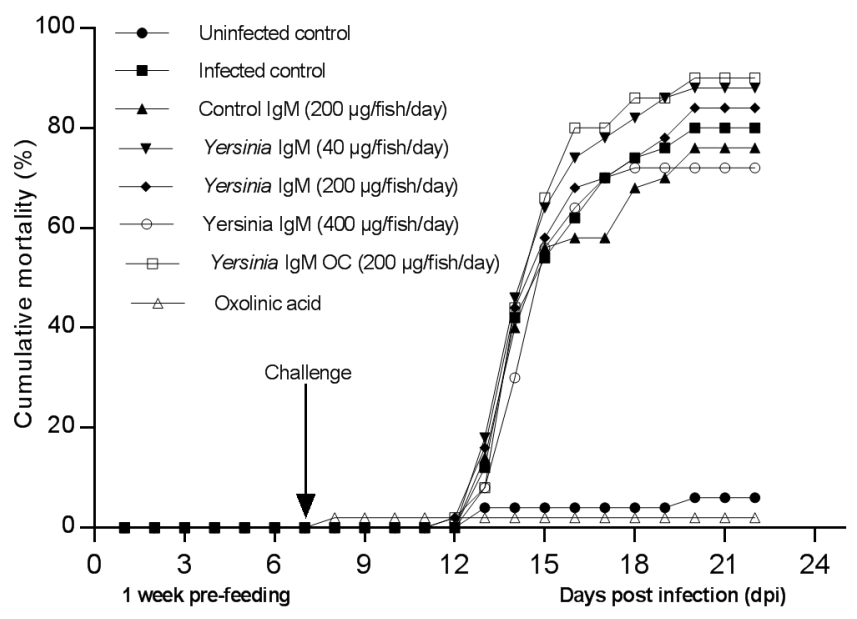


Figure 1. Yersinia ruckeri specific antibody titer from vaccinated and unvaccinated fish. Fish were vaccinated with $Y$. ruckeri $3 \times 10^{10} \mathrm{CFU} / \mathrm{ml}$ (containing both biotype 1 and 2 ) in Freund's incomplete adjuvant (1:1). ELISA plates were coated with sonicated lysate of $Y$. ruckeri $(5 \mu \mathrm{g} / \mathrm{ml}$ protein concentration) and tested for antibody titer. Each symbol represents a single fish and asterisk $(*)$ on the top indicates a significantly different $(\mathrm{P} \leq 0.05)$ from the unvaccinated control group.

Figure 2. The sandwich ELISA developed for quantification of rainbow trout IgM. ELISA plates were coated with monoclonal antibody against rainbow trout IgM (1/1000 dilution) and detection antibody was based on the same antibody with biotinylation. Pooled samples from vaccinated or unvaccinated fish were run in dilutions and calculation of IgM was performed based on the standard purification. Asterisk sign $(*)$ on the top indicates a significantly different $(\mathrm{P} \leq 0.05)$ from the control group.

Figure 3. Binding of specific antibody against Yersinia ruckeri after elution from alginate microparticles. The IgM encapsulated alginate microparticles were incubated with sodium bicarbonate $\mathrm{pH} 8.2$ for 4 days and the re-extracted IgM $(100 \mu \mathrm{l})$ was used for testing bio-activity in pathogen-specific ELISA (plate coated with sonicated lysate of $Y$. ruckeri $(5 \mu \mathrm{g} / \mathrm{ml}$ protein concentration)).

Figure 4. Quality of specific antibody against Yersinia ruckeri following elution from alginate microparticles. The IgM encapsulated alginate microparticles were incubated with sodium bicarbonate $\mathrm{pH} 8.2$ for 4 days and the re-extracted IgM was used for running SDS-PAGE (left) and Western Blot (right) to test if encapsulation process leads to any changes in protein integrity and to test the release of encapsulated IgM at different $\mathrm{pH}$.

Figure 5. Cumulative mortality of fish after challenge infection with Yersinia ruckeri biotype 2. Fish were fed with a diet containing anti-Yersinia ruckeri antibody (IgM) for three weeks (1-week pre-feeding before challenge and 2 weeks feeding during the infection). A total of eight groups in duplicate was included in the experiment. Three control groups were included in the study where one group was fed with ordinary feed coated with plain alginate (this group was not given infection and served as uninfected control) and the second group was given the same feed type as group 1 but this group was given infection (infected control). The third control group was given alginate encapsulated IgM supplemented feed purified from the unvaccinated fish and infection was applied. Three groups were given immunoglobulin in feed (three dosages). The seventh group of fish was fed with anti-Yersinia ruckeri immunoglobulin directly oil coated on feed. And the last group (8) was fed with antibiotic (oxolinic acid: $1.25 \mathrm{~g} / \mathrm{kg}$ feed) coated feed (positive control). The experimental groups are detailed in table 1. For infection, Fish were exposed to $48 \mathrm{~h}$ culture of $Y$. ruckeri (100415-1/4) bacterial soup for $4 \mathrm{~h}$ with a final bacterial concentration of $1.2 \times 10^{8} \mathrm{CFU} / \mathrm{ml}$. 


\section{Highlights}

- Yersinia ruckeri specific IgM was purified and encapsulated in alginate mircoparticles

- Bio-activity and integrity of encapsulated IgM remain intact

- IgM encapsulated microparticles were top-coated in fish feed

- Feeding and challenge experiment was performed to evaluate protection

- Highest dose of IgM fed group showed 10\% lower mortality indicating its positive effect. 